\title{
Extraction and Solubilization Methods Suitable for Proteomic Analysis of Common Bean Seed of Ivory Coast
}

\author{
Louise Ocho-Anin Atchibri', Etienne Dako2*, Benoit Sarazin ${ }^{3}$ \\ ${ }^{1}$ Department of Food Science and Technology, Laboratory of Nutrition and Food Safety, University of Nanguy Abrogoua, Abidjan, Ivory \\ Coast \\ ${ }^{2}$ School of Food Science, Nutrition and Family Studies (Faculty of Health Science and Community Services), Laboratoire of Biotechnology \\ and Human Nutrition, University of Moncton, New-Brunswick, Canada \\ ${ }^{3}$ Laboratory of Proteomic Solutions, Saint-Marcel, France \\ Email:*etienne.dako@umoncton.ca
}

How to cite this paper: Atchibri, L.O.-A., Dako, E. and Sarazin, B. (2016) Extraction and Solubilization Methods Suitable for Proteomic Analysis of Common Bean Seed of Ivory Coast. Food and Nutrition Sciences, 7, 1330-1338.

http://dx.doi.org/10.4236/fns.2016.714121

Received: August 17, 2016

Accepted: December 2, 2016

Published: December 5, 2016

Copyright $\odot 2016$ by authors and Scientific Research Publishing Inc. This work is licensed under the Creative Commons Attribution International License (CC BY 4.0).

http://creativecommons.org/licenses/by/4.0/ (c) (i) Open Access

\begin{abstract}
The extraction and solubilization of proteins from seeds of Phaseolus vulgarisms for two-dimension polyacrylamide gel electrophoresis (2D-PAGE) and analysis by mass spectrometry are very sensitive procedures. In this study, we used two methods of extraction and solubilization of proteins, the urea/thiourea method and the trichloroacetic acid (TCA)/acetone precipitation method, in order to determine their effectiveness in separating proteins from bean seeds by 2D-PAGE. In both methods, proteins were well separated by 2D PAGE with minor variations in the protein pattern. These two extraction methods showed that it was possible to separate hundreds of very resolvent proteins by $2 \mathrm{D}$ electrophoresis. A protein spot was selected on the 2D-PAGE gel, digested with trypsin and analyzed by mass spectrometry (LCMS/MS). The results suggest that thiourea/urea and TCA methods were effective and reliable for the extraction and solubilization for $2 \mathrm{D}$ analysis of proteins from seeds of Phaseolus vulgaris.
\end{abstract}

\section{Keywords}

Proteomics, Bean Seeds, Phaseolus vulgaris, 2D-PAGE, LC-MS/MS

\section{Introduction}

The extraction and solubilization of proteins for proteomic analysis is a milestone for subsequent analysis by polyacrylamide two-dimension electrophoresis (2D-PAGE) [1]. By optimizing the methods of sample preparation, or the extraction of proteins resolubi- 
lized in a buffer compatible with the electrophoresis, we improved the conditions so that separation by isoelectric focusing (IEF) is possible [1] [2].

Indeed, much progress has been made [3] [4] in sample application with the use of immobilized $\mathrm{pH}$ gradient strips (IPG) for isoelectric focusing (IEF). However, the extraction and solubilization are difficult to implement in legumes. The study of legume (soy) proteomics has already been reported [5]; however these authors have underlined the difficulty of extracting and solubilizing its proteins.

The search for new techniques of protein extraction remains a challenge for proteomic analysis because of the presence of contaminants affecting the performance in twodimensional (2D) analyses. To separate a wide range of proteins, it is important to find effective methods of extraction and solubilization. This study aimed to test two different methods of extraction and solubilization of proteins from bean seeds (Phaseolus vulgaris) from Ivory Coast, in order to assess their compatibility with IEF and the quality of the electrophoretic separation.

\section{Materials and Methods}

\subsection{Plant Material}

Bean seeds (Phaseolus vulgaris) were collected at the National Center for Agricultural Research CNRA (Ivory Coast).

\subsection{Methods}

\subsubsection{Protein Extraction}

Bean seeds were crushed with a pestle in a mortar to a fine powder and subsequently extracted by one of the following methods: Urea/Thiourea and or Trichloroacetic acid (TCA)/acetone precipitation.

\subsubsection{Extraction and Solubilization in Thiourae/Urea Buffer}

One gram of crushed seeds was washed two times with hexane to remove lipids. After vacuum drying, Protein was extracted by vortexing $100 \mathrm{mg}$ of seed powder with $1.5 \mathrm{ml}$ of extraction buffer containing CHAPS (4\%), urea (5 M), thiourea (2 M), (0.8\%) ampholytes [pH 3 - 10] and DTT (65 $\mathrm{mM}$ ) for $5 \mathrm{~min}$ at room temperature. The extract was centrifuged at 13,000 rpm for 30 minutes at room temperature. The supernatant was collected for the two-dimensional (2D) analysis.

\subsubsection{Extraction and Solubilization in Trichloroacetic Acid/Acetone Buffer}

For this method, bean seeds were powdered in liquid nitrogen using mortar and pestle. Bean seeds powder $(100 \mathrm{mg}$ ) was homogenized with $5 \mathrm{ml}$ of a solution containing $10 \%$ $(\mathrm{w} / \mathrm{v})$ trichloroacetic acid (TCA) in acetone with $0.07 \%(\mathrm{v} / \mathrm{v}) 2$-mercaptoethanol for 2 hours $30 \mathrm{~min}$ at $-20^{\circ} \mathrm{C}$ and then centrifuged at $4000 \mathrm{rpm}$ for 30 minutes at room temperature. Proteins of the crushed seeds were precipitated for 2 hours $30 \mathrm{~min}$ at $-20^{\circ} \mathrm{C}$ in an acetone/TCA buffer containing $10 \%$ of TCA, $0.07 \%$ of 2 -mercaptoethanol and acetone, and the mixture was centrifuged at $4000 \mathrm{rpm}$ for 1 hour at $-20^{\circ} \mathrm{C}$. Then, the pellet was rinsed twice at $-20^{\circ} \mathrm{C}$ for 1 hour in 2-mercaptoethanol and acetone buffer 
and centrifuged as previously done. After 2 hours and $15 \mathrm{~min}$ of vacuum drying, the pellet obtained was resuspended in a solution containing urea (9 M), CHAPS (1\%), DTT (1\%) and ampholytes [pH 3 - 10] (4\%) and solubilized by stirring for $30 \mathrm{~min}$. In order to eliminate insoluble compounds, a final centrifugation for $10 \mathrm{~min}$ at 13,000 rpm was performed and the protein solution recovered. This solution was ultracentrifuged (200,000 $\mathrm{g}, 30 \mathrm{~min})$ for 1 hour at room temperature. The resulting supernatant was stored at $-20^{\circ} \mathrm{C}$ until use in 2D-PAGE analysis.

\subsubsection{Isoelectric Focusing}

The first dimension was performed on the Protean IEF Cell apparatus (Bio-Rad). Strips of immobilized $\mathrm{pH}$ gradient (IPG) $24 \mathrm{~cm}$ long covering a linear $\mathrm{pH}$ range from 3 to 10 linear were used. The samples were deposited with the strips rehydration solution during the first dimension (9 M urea, 4\% CHAPS, $0.6 \%$ ampholytes and $20 \mathrm{mM} \mathrm{DTT}$ ) for $13 \mathrm{~h}$ at $20^{\circ} \mathrm{C}$. The strips were protected from dehydration and oxidation by coating with mineral oil. The first dimension was held performed at $20^{\circ} \mathrm{C}$ and was divided into five steps to obtain at least 100,000 Volts per hour. The strips were then directly used for the second dimension. Before the implementation of the second electrophoresis, the gels of the first dimension (IPG) were equilibrated in two different buffers. The strips were equilibrated for $15 \mathrm{~min}$ in $2 \mathrm{ml}$ of buffer solution containing urea (6 M), SDS (2\%), Tris- $\mathrm{HCl}(0.375 \%)$, glycerol (20\%) and DTT $130 \mathrm{Mm}$. Then, these strips were placed for $20 \mathrm{~min}$ in the same buffer but by replacing DTT with $135 \mathrm{mM}$ iodoacetamide.

\subsubsection{Stage of the Second Dimension Gel $12 \%$ Acrylamide}

The second dimension was performed at $20^{\circ} \mathrm{C}$. Balanced strips were placed by placing the equilibrated strips on a $12 \%$ acrylamide gel (Duracryl TM) without stacking gel. The strips were fixed at the top of the acrylamide gel with a solution containing $1 \%$ agarose with low melting point, diluted in a migration buffer. Migration was stopped after $7 \mathrm{~h}$ of migration at constant voltage of $200 \mathrm{~V}$, that is to say $1400 \mathrm{~V} /$ Hour. The migration front was determined by the migration of bromophenol blue. At the end of the second dimension, the gels were rinsed three times for $1 \mathrm{~min}$ with MilliQ water and fixed overnight in a solution of methanol (30\%) and acetic acid (10\%). The gels were then rinsed twice in a solution of methanol (10\%) for $10 \mathrm{~min}$, placed for 1 minute in a solution of solubilization composed by sodium thiosulfate $(0.02 \%)$, washed for $1 \mathrm{~min}$ with water and incubated for $30 \mathrm{~min}$ in a solution of silver nitrate $(0.01 \%)$ at $4{ }^{\circ} \mathrm{C}$ with shaking. After washing twice for 1 minute with water, the gels were placed in the revealing solution (0.037\%) (1.2\% formaldehyde in sodium carbonate), under stirring, until the appearance of spots. The reaction was stopped by immersing gels in acetic acid, $1 \%$, and kept them in a solution of $1 \%$ acetic acid.

\subsection{Digestion of Proteins and Extraction of Peptides to Analyze}

The proteins of interest were cut from the gel and transferred into eppendorf tubes. The pieces of gel underwent a first wash of $30 \mathrm{~min}$ at room temperature in $500 \mathrm{~mL}$ of 100 $\mathrm{mM}$ carbonate buffer and then were washed again in the same buffer but at $20 \mathrm{mM}$. 
The pieces of gel were then subjected to a dehydration which facilitates the penetration of trypsin and favour digestion. Fifty $\mu \mathrm{l}$ of acetonitrile were added and after 15 minutes without agitation, drying was carried out in a lyophilizer (Savant UVS400A). The pieces of gel were rehydrated with $10 \mathrm{~mL}$ of digestive solution (trypsin $0.1 \mathrm{mg} / \mathrm{mL}$ ) and after 15 minutes at room temperature, $50 \mathrm{~mL}$ of carbonate buffer $(20 \mathrm{mM})$ were added and digestion was performed at $37^{\circ} \mathrm{C}$ for $7 \mathrm{~h}$. The digestive solution was then recovered and washing was performed in a mixture (50/50) acetonitrile/carbonate buffer, $20 \mathrm{Mm}$. A second washing with the mixture $(100 \mathrm{uL})$ acetonitrile/TFA/water (01/10/1989) allowed extraction of the remaining peptides in the gel. The peptides were concentrated by drying in Speed Vac and resuspended in formic acid $0.1 \%$ and in acetonitrile $3 \%$ for analysis with mass spectrometry LC-MS-MS.

\section{Sample Preparation and LC-MS-MS Analysis}

Five $\mu \mathrm{L}$ of the peptide solution were injected for LC-MS-MS trap analysis. The ions formed in the source enter in a first analyzer that allows the selection of the ion which will be fragmented. This ion is the only one which comes out of the first analyzer and then will collide with neutral gas molecules placed in a collision chamber. The search in protein databases is carried out by the program Mascot 2.0 (www.matrixscience.com).

The mass spectra were analyzed using the Mascot software in the database NCBInr $20,090,324$ (8,097,822 sequences; 2,786,930,639 residues) with the Taxonomy: Viridiplantae (Green Plants) (632,568 sequences) with the following parameters:

Type of search: MS/MS Ion Search Enzyme: Trypsin

Variable modifications: Carbamidomethyl (C), Carboxymethyl (C), Oxidation (M)

Mass values: Monoisotopic

Protein Mass: Unrestricted

Peptide Mass Tolerance: $\pm 1.6 \mathrm{Da}$

Fragment Mass Tolerance: $\pm 0.8 \mathrm{Da}$

Max Missed Cleavages: 1

Instrument type: ESI-TRAP

\section{Results and Discussion}

The thiourea/urea and the acetone/TCA methods of extraction and solubilization were compared in this study on Phaseolus vulgaris seed proteins. The Thiourea/Urea method (Figure 1(a)) showed a good proteins solubilization for proteomic analysis of Phaseolus vulgaris seed proteins. Indeed, this increase in solubility of the thiourea/Urea method could be explained by the combined effect of chaotropic and reducing agents as well as detergents. Furthermore, the urea and thiourea, two chaotropics solubilize proteins. Regarding the CHAPS, which is also a detergent, it also solubilizes proteins. It is not charged, that makes it compatible with IEF. Furthermore dithiothreitol (DTT), a reducing agent, has been shown to improve the proteins solubility during IEF and to increase the protein transfer during the second dimension [6]. Thus, in our study, the combination of two chaotropic agents with a detergent and a reducing agent has increased the solubility and resolution of proteins (Figure 1). The red circles highlight a 


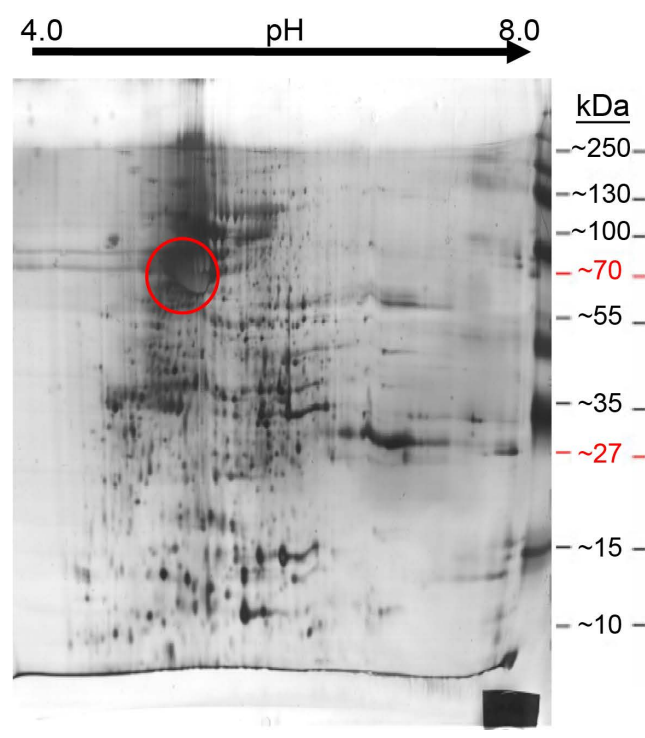

(a)

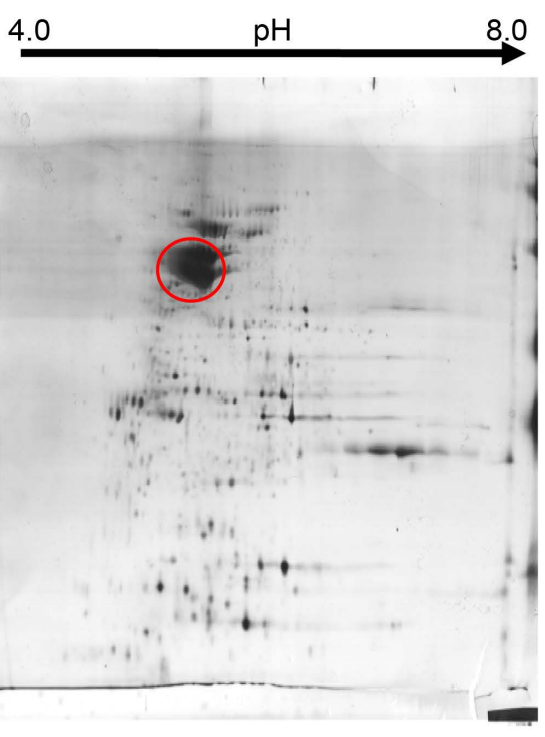

(b)

Figure 1. Two-dimensional electrophoresis gel of Phaseolus vulgaris proteins extracted using various methods: (a) Thiourea/urea methods and (b) TCA/acetone precipitation methods.

group of abundant proteins which were not well separated because they were present in excessive amounts.

This result is consistent with the findings of Mechin [7] Damerval [8]. The works [9] showed that the addition of thiourea to urea increased the chaotropic nature and led to a better solubilization of many proteins. Other studies showed that using this extraction method provided better solubilization of soybean proteins [10]. Sample preparation by the Thiourea/Urea method for isoelectrophoresis (IEF) is complex. Indeed, IEF imposes two constraints: to respect the protein charge and work at low ionic strength. The first constraint is obvious because of the separation principle applied, and disclaims any charged detergent which, by its binding to proteins, could modify their charge. The second constraint is, however, less obvious because in the case of IEF, the electric charge of proteins is initially low and gradually decreases as they approach their isoelectric points. Accordingly, strong fields must be used, and for long enough times. At these values, the presence of salt induces a huge joule effect, which therefore requires the preparation of the sample in environments of low ionic strength. The acetone/TCA precipitation method (Figure 1(b)), also improved the solubilization of Phaseolus vulgaris seed proteins.

With this method, proteins were first precipitated. After the precipitation, we used a single chaotropic agent, a detergent and a reducing agent. So, the fact of precipitating the proteins makes the solubilization easier. Our results confirm the work [11]; who found that the resolution of acetone/TCA precipitation improves the solubility of protein spots. These authors explain this by the inhibition of proteolytic activity. [2] [12] had also shown a high resolution of proteins by $2 \mathrm{D}$ electrophoresis using a precipitation method with acetone and trichloroacetic (TCA) with soy proteins and Arabidopsis thaliana on wheat seedlings. A study of Natarajan [13] showed that the trichloroacetic 
acid (TCA) precipitation and the thiourea/urea methods are quite similar, efficient and reliable for 2D separation of soy proteins. Other studies have also shown that the use of these extraction methods allows a better solubilization of proteins. In order to denature, reduce and well solubilize various proteins found in a complex biological sample such as Phaseolus vulgaris, these solubilization media contain a reducing agent of disulfide bonds, a neutral chaotropic agent (urea) at a high concentration, an electrically neutral surfactant and a buffer at low concentration, which must meet the chemical and electrical requirements of the IEF [3]. This buffer system often contains carrier ampholytes which have the advantage to increase the proteins solubility and smooth the conductivity of immobilized $\mathrm{pH}$ gradients.

The extraction and solubilization is the first and therefore crucial step in proteomic analysis. Indeed, an inadequate extraction and solubilization of protein causes poor migration in the first dimension and leads to poor resolution of 2-D gels. It is important to note that the terms of sample extraction and solubilization will determine the success of proteomic analysis.

Since the aim is to obtain individualized proteins after separation by two-dimension electrophoresis for identification by mass spectrometry, it is necessary to make a good extraction. The cells destruction must be achieved while preserving the integrity of proteins [14]. The extraction is fairly difficult with proteins of legumes [3]. Thus, in our study we were able to extract and solubilize proteins from a sample of Phaseolus vulgaris seeds that might be explained by the fact that the seed of Phaseolus vulgaris does not contain large quantities of fat. The two solubilization methods used allowed to remove and eliminate non-protein components that interfere with IEF as non-protein impurities can affect the quality of the $2 \mathrm{D}$ separation. The choice of the revealing method depends on the desired resolution and the type of analysis to be performed on proteins after separation. To identify specific proteins, the gels from both experiments were stained with silver nitrate following a method compatible with subsequent mass spectrometry. However, there are many other methods for detecting separated proteins [15]. With this silver nitrate revealing method, a total of 971 spots were identified for the Urea/Thiourea method (Figure 2(a)) and 923 spots detected for the acetone/TCA precipitation method (Figure 2(b)). Then, a spot of interest was excised from each method gel, digested with trypsin and analyzed by mass spectrometry LC-MS/MS. The results gave us high quality spectra (Figure 3 and Figure 4).

Interest spots identified as number 1453 and 1527 with molecular weight $18 \mathrm{kDa}$ and $18.5 \mathrm{kDa}$, and with pI 4.7 and 4.9 respectively. The peptide profiles of the spot 1453 and 1527 (Figure 3 and Figure 4), do not correspond to peptidic protein profiles in the consulted databases. Each peptide profile analyzed by the Profound software provides recovery rate from $10 \%$ to $36 \%$ for 1453 spot and $63 \%$ for 1527 spot.

We were however unable to identify the specific proteins of interest because of a lack of data on Phaseolus vulgaris in protein databases. However protein families can be identified by homology to other plant species protein. Therefore, based on the molecular weight (MW) of fragmented ion son, isoelectric point (pI) and the recovery rate, the 


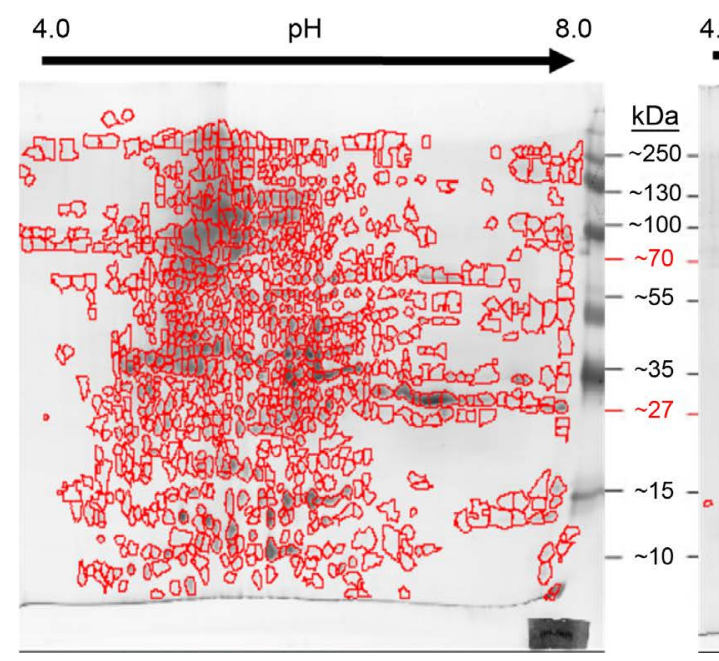

(a)

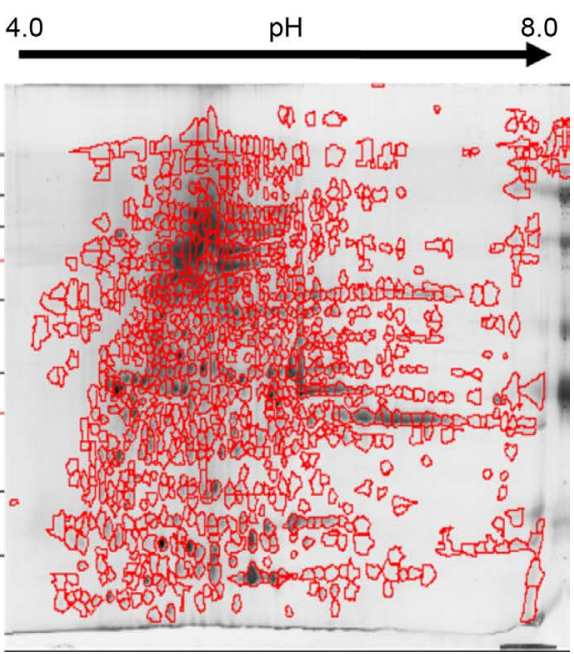

(b)

Figure 2. Two-dimension electrophoresis gel of Phaseolus vulgaris proteins extracted using Thiourea/urea methods and TCA/acetone precipitation methods after coloration.

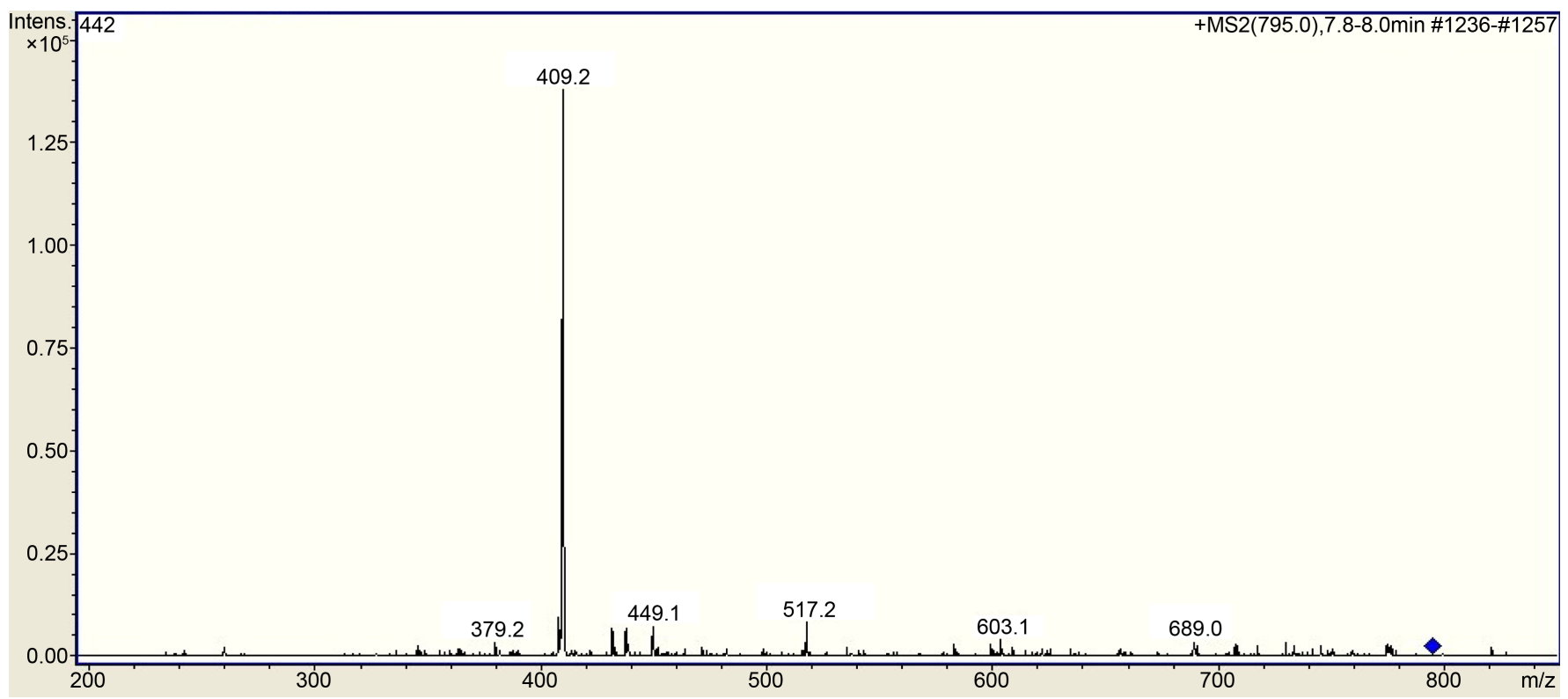

Figure 3. Peptide profile obtained by liquid chromatography-mass spectrometry in tandem or MS/MS of trypsin digestion of spot BS_1453_MS1 peptide 1.

1453 spot could correspond to the 11S globulin and the 1527 globulin.

\section{Conclusion}

These two extraction methods allowed satisfactory separation of proteins by $2 \mathrm{D}$ electrophoresis, even though these separation techniques do not allow seeing all the proteins. It is possible to make comparative electrophoresis between two varieties (or two conditions of seeds storage) of Phaseolus vulgaris for example to highlight proteins that differ (quantitatively or qualitatively). The mass spectrometry analysis is limited by the 


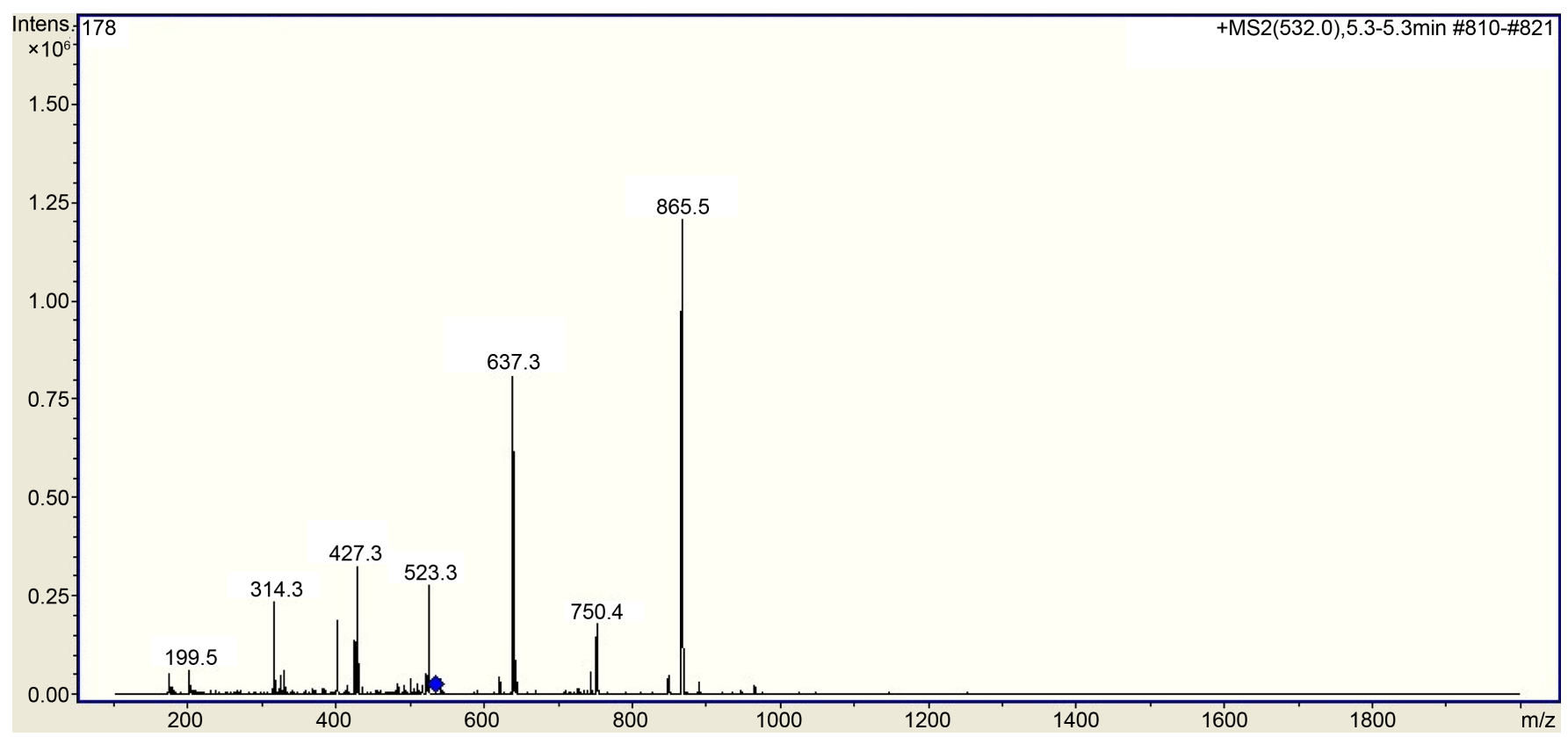

Figure 4. Peptide profile obtained by liquid chromatography-mass spectrometry in tandem or MS/MS of trypsin digestion of spot BS_1527_MS2 peptide 1 .

presence of Phaseolus vulgaris proteins, but proteins functions could undoubtedly be identified by homology with proteins from other plant species.

\section{References}

[1] Herbert, B. (1999) Advances in Protein Solubilization for Two-Dimensional Electrophoresis. Electrophoresis, 20, 660-663. http://dx.doi.org/10.1002/(SICI)1522-2683(19990101)20:4/5<660::AID-ELPS660>3.0.CO;2Q

[2] Berkelman, T., Stenstedt, T., Bjellqvist, B., Laird, N., McDowell, M., Olsson, I. and Westermeier, R. (1998) 2D Electrophoresis Using Immobilized PH Gradients: Principles and Methods. Amersham Biosciences, Piscataway, NJ.

[3] Dunn M.J. and Burghes, A.H.M. (1983) High Resolution Two-Dimensional Polyacrylamide gel Electrophoresis: I. Methodological Procedures. Electrophoresis, 4, 97-116. http://dx.doi.org/10.1002/elps.1150040202

[4] Gorg A., Obermaier, C., Boguth, G., Harder, A., Scheibe, B., Wildgruber, R. and Weiss, W. (2000) The Current State of Two-Dimensional Electrophoresis with Immobilized pH Gradients. Electrophoresis, 21, 1037-1053.

http://dx.doi.org/10.1002/(SICI)1522-2683(20000401)21:6<1037::AID-ELPS1037>3.0.CO;2$\underline{\mathrm{V}}$

[5] Adessi, C., Miege, C., Albrieux, C. and Rabilloud, T. (1997) Two-Dimensional Electrophoresis of Membrane Proteins: A Current Challenge for Immobilized pH Gradients. Electrophoresis, 18, 127-135. http://dx.doi.org/10.1002/elps.1150180124

[6] Luche, S., Diemer, H., Tastet, C., Chevallet M., Dorsselaer, A.V., Leize-Wagner, E. and Rabilloud, T. (2004) About Thiol Derivatization and Resolution of Basic Proteins in TwoDimensional Electrophoresis. Proteomics, 4, 551-561.

http://dx.doi.org/10.1002/pmic.200300589 
[7] Mechin, V., Consoli, L., Guilloux, M.L. and Damerval, C. (2003) An Efficient Solubilization Buffer for Plant Proteins Focused in Immobilized pH Gradients. Proteomics, 3, 1299-1302. http://dx.doi.org/10.1002/pmic.200300450

[8] Damerval, C., De Vienne, C., Zivy, M. and Thiellement, H. (1986) The Technical Improvements in Two-Dimensional Electrophoresis Increase the Level of Genetic Variation Detected in Wheat Seedling Proteins. Electrophoresis, 7, 52-54. http://dx.doi.org/10.1002/elps.1150070108

[9] Rabilloud, T., Adessi, C., Giraudel, A. and Lunardi, J. (1997) Improvement of the Solubilization of Proteins in Two-Dimensional Electrophoresis with Immobilized pH Gradients. Electrophoresis, 18, 307-316. http://dx.doi.org/10.1002/elps.1150180303

[10] Mooney, B.P. and Thelen, J.J. (2004) High-Throughput Peptide Mass Fingerprinting of Soybean Seed Proteins: Automated Workflow and Utility of UniGene Expressed Sequence Tag Databases for Protein Identification. Phytochemistry, 65, 1733-1744. http://dx.doi.org/10.1016/j.phytochem.2004.04.011

[11] Pridmore, A.M., Devine, D.A., Bonass, W.A. and Silley, P. (1999) Influence of Sample Preparation Technique on Two Dimensional Gel Electrophoresis of Proteins from Porphyromonas gingivalis. Letters in Applied Microbiology, 28, 245-249. http://dx.doi.org/10.1046/j.1365-2672.1999.00544.x

[12] Santoni, V., Bellini, C. and Caboche, M. (1994) Use of Two-Dimensional Protein-Pattern Analysis for the Characterization of Arabidopsis thaliana Mutants. Planta, 192, 557-566. http://dx.doi.org/10.1007/BF00203594

[13] Natarajan, S., Chenping, X., Thomas, J., Caperna, C., Wesley, M. and Garrett, D. (2003) Comparison of Protein Solubilization Methods Suitable for Proteomic Analysis of Soybean Seed Proteins. Analytical Biochemistry, 342, 214-220. http://dx.doi.org/10.1016/j.ab.2005.04.046

[14] Rabilloud, T. and Santoni, V. (2000) Le protéome: Nouvelles approches expérimentales et systèmes étudiés.

[15] Natarajan, S., Xu, C.P., Caperna, T.J. and Garrett, W.M. (2005) Comparison of Protein Solubilization Methods Suitable for Proteomic Analysis of Soybean Seed Proteins. Analytical Biochemistry, 342, 214-220. http://dx.doi.org/10.1016/j.ab.2005.04.046

Submit or recommend next manuscript to SCIRP and we will provide best service for you:

Accepting pre-submission inquiries through Email, Facebook, LinkedIn, Twitter, etc.

A wide selection of journals (inclusive of 9 subjects, more than 200 journals)

Providing 24-hour high-quality service

User-friendly online submission system

Fair and swift peer-review system

Efficient typesetting and proofreading procedure

Display of the result of downloads and visits, as well as the number of cited articles

Maximum dissemination of your research work

Submit your manuscript at: http://papersubmission.scirp.org/

Or contact fns@scirp.org 